\title{
Betamethasone Sodium Phosphate
}

National Cancer Institute

\section{Source}

National Cancer Institute. Betamethasone Sodium Phosphate. NCI Thesaurus. Code

C47964.

The disodium salt of the 21-phosphate ester of betamethasone, a synthetic glucocorticoid with metabolic, immunosuppressive and anti-inflammatory actions.

Betamethasone sodium phosphate binds to specific intracellular glucocorticoid receptors and subsequently binds to DNA to modify gene expression. The synthesis of certain antiinflammatory proteins is induced while the synthesis of certain inflammatory mediators is inhibited. As a result, there is an overall reduction in chronic inflammation and autoimmune reactions. 